\title{
Application of Restorative Justice Theory in Aboriginal Criminal Justice Process in Canada: An Analysis
}

\section{Syed Robayet Ferdous}

Assistant Professor \& Head, Centre for Legal Research (CLR), Department of Law \& Justice, Southeast University, Dhaka, Bangladesh. Now Graduate Studies Research Scholar, Department of Law, University of Ottawa, Ontario, Canada.

\section{Repon Khan}

Executive Coordinator, Japan International Cooperation System, Japan.

\section{B. N. Dulal}

Dr, Consultant, B. N. Dulal \& Associates, Dhaka, Bangladesh.

\begin{abstract}
Aboriginal is the first nation in Canada. Their beliefs and behaviour, culture and tradition, and the socioeconomic process are different from traditional contemporary Canadian. Thus they do not believe traditional litigation or win-lose contest of criminal justice process rather prefer the resolution by understanding. The Canadian traditional criminal justice system comes from western approach; therefore, this system is a mismatch with aboriginal traditional culture and value. There is a significant difference between the aboriginal justice process and predominant traditional criminal justice process exist in Canada. Canadian traditional criminal justice system does not acknowledge specialized aboriginal background. As a result, contemporary Canadian criminal justice system cannot ensure the aboriginal's right. Therefore, the different study shows that the alternative criminal justice system is urgently needed for Canadian aboriginal people. This alternative criminal justice system is referred here as Restorative Justice (RJ) process.
\end{abstract}

Keywords: Aboriginal, Restorative Justice, Traditional Criminal Justice, Canada.

JEL Classification: K14, K15, K41.

(C) The Authors, 2018. This article is published with open access at Sumy State University.

\section{Introduction}

Restorative Justice (RJ) is a system in which victim, offender, and other individual or community member affected by an offence join together actively in the resolution of matters arising from the offence, usually with the help of a facilitator (United Nations, Office of Drugs and Crimes, 2006). However, this process is not permitted by Canadian traditional criminal justice system. As the Canadian traditional criminal justice process is different from the aboriginal background, therefore, the aboriginal people are unable to follow the Canadian traditional criminal justice system.

As a result, aboriginal people remarkably found guilty of a crime, deliberately represent in the Canadian prison, and therefore, it is reasonable to permit alternative criminal justice system for aboriginal people in Canada (Paula Maurutto and Kelly Hannah-Moffat, 2016). Integration of aboriginal cultural circumstances as well as specialized aboriginal knowledge in the Canadian criminal justice system is a long debate. This debate has been taken place after the reformation of the Canadian sentencing law in 1996 (David Daubney, 2002) and after that, in $R v$. Gladue, (1999) case where introduced restorative justice process in the aboriginal criminal justice system (Paula Maurutto and Kelly Hannah-Moffat, 2016). Later on, the decisions in R. v. Borden (2003), R. v. Kakekagamick (2006), and R. v. Ipeelee (2012) subsequently recognized the restorative justice process in the aboriginal criminal justice system. Because this process reflects the aboriginal idea of justice and offer an alternative remedy to prison, and in many circumstances suitable for aboriginal peoples.

\section{Research Question}

Aboriginal is the first nations in Canada and came from a specialized background. Therefore, they have rights to get criminal justice by integrating their inherent background (restorative justice by involving community) instead of Canadian traditional criminal court process. However, the restorative justice theorist (Price Marty, 2000: 8-11) suggests that: 
"The approach is based on a theory of justice that considers crime and wrongdoing to be an offence against an individual or community, rather than the State. Therefore, this theory is not suitable for criminal justice process".

Moreover, people raise serious questions about the partiality in the restorative justice process, which is also reflected from (Law Commission of Canada, 2003: 57-58) statement that:

"A number of women's groups have cautioned that communities involved in restorative justice initiatives may be tempted to provide more support to offenders than to victims".

Therefore, this manuscript has set the following research question:

Does restorative criminal justice process for aboriginal people is more suitable than that of Canadian traditional criminal justice process?

This study is arguing that the application of restorative justice theory in the aboriginal criminal justice system is a suitable process. Notwithstanding the fact, however, the ample application of restorative criminal justice theory may intrude the pavement of exact outcome of criminal justice. Thus this paper suggests that in the restorative criminal justice process court will have to apply its sound and judicial mind as well as reasonable guided by the judicial principle. ${ }^{1}$

Therefore, in concluding remarks, suggesting court based restorative justice process by integrating trained aboriginal people. But this paper does not suggest to follow 'healing circle' restorative justice system for the serious criminal offence because this process does not allow court involvement in any stage of a settlement.

As a whole, this paper discusses theory and legal theory, restorative justice theory, restorative justice theory in the criminal justice system in Canada, restorative justice theory in $R v$. Gladue case as well as the success of restorative justice theory in the criminal justice process.

\section{Theory and Legal Theory}

The theory is a guideline for reaching a destination. It may be a social theory, political philosophy, economic theory, literary theory and so on. However, in reality, the theory remains up to a policy rather than of reaching goals (McMurray Foster, 1955). Therefore, the theory is always criticized by critics.

The law and justice have deeply associated with each other and justice are one of the essential concepts of the legal theory. Therefore, restorative justice theory is one of the pillars of judicial success. Although the legal theory is a guideline for the judicial process, this theory is not beyond criticism.

Instead of state, the legal scholar defines legal theory, and the judicial body follows legal theory within a framework of the judicial process. Therefore, in case of conflict between legal theory and statutory criminal law, a statutory criminal law shall prevail. Although, in the absence of statutory criminal procedural law court may allow legal theory as a guideline of the judicial process. It's true that court has a judicial obligation to follow the statutory criminal law. However, the court may allow the legal theory only when the existing statutory criminal law is ambiguous or absence. In interpreting statutory law court may apply its discretionary power but rare in criminal cases. In case of application of theory, the court may interpret theory widely. Therefore, interpretation of the legal theory is ample, and arbitrary interpretation and application of legal theory may derail the path of the criminal judicial norm as well as the violation of legal rights. Thus, the restorative criminal justice theory may apply to aboriginal cases as an exceptional circumstance.

\section{Restorative Justice Theory}

There is no comprehensive definition of restorative justice theory. In special circumstances, the judicial body allows restorative guideline to provide justice in an alternative way. According to Price Marty (2000: 11), restorative justice approach is based on a theory of justice that has dealt with individual or community. So, therefore, restorative justice system propose to maintain internal value in community resident (John Braithwaite, 2002). Nowadays, the restorative justice process has introduced in criminal justice process for settling a criminal dispute in an alternative way. Mainly this process is introduced for two reasons: to reduce

\footnotetext{
${ }^{1}$ There is four issue of judicial principles including, the judge will indorse high standards of judicial conduct to strengthen public confidence... see more: Canadian Judicial Council, "Ethical Principles of Judges" ccm.gc.ca/cmslib/general/news_pub_judicialconduct_Principles_en.pdf.
} 
the backlog of criminal cases, and to settle the criminal dispute in special circumstances. Also, advocates of restorative justice theory argue traditional court process harms people relationship as well as the community, while the restorative justice process repairs the harm and encounter disputant in a transforming way (John Braithwaite, 2002). From that point of view, restorative justice system emphasizes repairing the harm commit by criminal behaviour. Therefore, this paper argues that it is the best cooperative processes that allow all willing stakeholders to meet, although other approaches are available when that is impossible. It can lead to the transformation of people, relationships and communities. Therefore, individual states allow restorative justice theory along with their existing statutory laws time being in force.

Favouring the restorative justice process, the other argument is, the system is as old as human society. It has been codified from personal law such as Sharia law, Roman law, many other community-based approaches and documents (Braithwaite, 1998). As this system come from ancient and different human community, therefore, this system integrates human society, and day by day this system is well-matched with the principle of the rule of law (Stephan Haggard et al., 2008) ${ }^{2}$ along with following ideology (Centre for Justice and Reconciliation, date of accessed: $6^{\text {th }}$ December, 2017):

$>$ people may commit a crime, but justice should be repaired this crime,

$>$ the people may affect by the offence, but parties have to participate in its resolution, and

the state has to maintain order and for the community to build peace.

The restorative justice evaluates the different way of thinking about offence and accountability of offender. This process not only emphases on repairing injury caused by the offence but also reducing future injury through offence prevention. It is imposed criminals to take the obligation for their action and for the damage they have caused. Thus this system mainly focuses on the victim and restitute victim from offenders (Van Ness et al., 2010: 21-22). It is a method of justice that personalizes the crime by having the victims and the offender mediate a restitution agreement to the satisfaction of each by involving community (Wikipedia, Restorative Justice, date of accessed: $23^{\text {rd }}$ November, 2017). This system allows victim-offender conference in the presence of a trained mediator. Also, the restorative approach allows family group conference, restorative conference, restorative community conference and so on. As this system allow victim and offender to mediate a restitution agreement, therefore, the restorative justice system has shown the maximum rates of victim satisfaction and offender accountability (Lawrence W. Sherman \& Heather Strang, 2007a). As a result, the restorative justice process is bias-free and allows in criminal justice process that emphasis on the rehabilitation of criminals through an understanding with victims-offenders and the community at large.

\section{Restorative Justice in Criminal Cases}

The quests of restorative justice are not only a change in practice but also a transformation in thinking. Critiques of restorative justice are discouraged from practicing restorative justice process in the criminal justice system (Price Marty, 2000). They argue that this theory has no precise guideline for using in criminal justice process. To tackle their statement, it can be said that, due to introducing restorative justice in the criminal justice system, individual states amended their criminal code, introduced the new policy in the criminal judicial system. Now, the contemporary restorative justice process practice in the criminal judicial system. This system is well designed by the individual state to fulfill their aspect. For instance, Canada, UK, Australia and New Zealand are the best example in the world. These countries have also formed community-based police for involving in the restorative justice process.

Individual states are forming courtrooms restorative justice process, which has visibly increased in commonwealth countries. Judges, prosecutors, and defence attorneys conduct the process. In courtroom restorative justice process fairness is ensure in each stage, and as a whole restorative justice system applied as a quasi-judicial ${ }^{3}$ process where the court is actively involved in the whole process.

As far as restorative justice guideline is a concern, one of the supporting evidence for restorative justice system mentioned in UN principles. To state that the schemes will follow the relevant provisions of the UN "Based Principles on the use of Restorative Justice Program in Criminal Matters". The principles are (Lawrence W Sherman and Heather Strang, 2007b):

\footnotetext{
${ }^{2}$ The rule of law is a legal principle that law will govern a nation, and will be opposed to being guided by decisions of individual persons. The rule of law has come to mean different things - ranging from security and order to the operations of courts and the administration of justice.

${ }^{3}$ It is a system where a court is also actively involved in the whole restorative process of justice.
} 
restorative processes should be used only with the free and voluntary consent of the parties (which may be withdrawn at any time);

$>$ agreements should be arrived at voluntarily and should be reasonable and proportionate;

$>$ parties should have the right to legal advice about the process;

$>$ before agreeing to participate, parties should be fully informed of their rights, the nature of the process, and the possible consequences of their decision;

$>$ neither victim nor offender should be coerced, or induced by unfair means, to participate in the process or to accept the outcome.

The Northern Ireland Office, in mid-2006, adopted these principles in its Draft Protocol for Community Based Restorative Justice Schemes (Lawrence W. Sherman and Heather Strang, 2007b). Tom R. Tyler (2003) suggests that the judicial authority and police should behave in ways that restore people the internal value of the community. The aim is to relink wrongdoers to an awareness of their social values as well as to uphold their social relationships. A field study in Canberra, Australia explores that the long-term impact of restorative justice experiments on law-abiding behaviour. The Sherman, Lawrence W. (1999) explores that the people express their greater respect for the law and order whose cases has processed via their traditional procedures. Lawrence W. Sherman and Heather Strang (2007b) suggests that both restorative justice and procedural justice models are:

"One important goal for legal authorities is to encourage activation of people's internal values so that they will feel personally responsible for rule-abiding conduct in the future".

Therefore, most of the common law countries adopted their legislation for integrating restorative justice in their criminal justice system. Also, the UN and European Council have approved different recommendations, manuals and other resources to guide their state parties in the effective use of restorative justice.

\section{Restorative Justice in Canadian Aboriginal Criminal Court}

Particularly in Canada, the restorative justice approach is not new. The system adopted in 1970 from a criminal case experiment Mennonite population (Mennonite and other practitioners, in Ontario, Canada, later on, Indiana, USA). ${ }^{4}$ However, from that time to date there is no practical development accept following three significant legal documents which acknowledged formal restorative justice system in Canada.

1st: the proclamation of Bill C-41 for alternatives to incarceration

2nd: Supreme Court of Canada (R. v. Gladue) decision for reducing aboriginal offender incarceration.

3rd: the 1999 federal Speech acknowledging the importance of restorative justice in Canadian society.

In the criminal justice system, there are four following specific entry points for the initiation of restorative justice practices in Canada (Jeff Latimer and Steve Kleinknecht, 2000).

\begin{tabular}{|c|l|l|l|}
\hline POLICE & \multicolumn{1}{c|}{ CROWN } & \multicolumn{1}{c|}{ COURTS } & \multicolumn{1}{c|}{ CORRECTIONS } \\
\hline pre-charge & post-charge & post-conviction & post-sentence \\
\hline & pre-conviction & pre-sentence & pre-reintegration \\
\hline
\end{tabular}

Among this four-point, at any stage offenders can be referred to a restorative justice system. However, in case of aboriginal issue, the restorative justice system is referred from the court. Although the application of restorative justice theory in criminal cases is not new, still there is a lack of knowledge about the effects of restorative justice practices in Canadian criminal justice system (Jeff Latimer and Steve Kleinknecht, 2000: 15).

In recent years restorative justice approach commonly used in the aboriginal community in Canada, when it has found that the traditional criminal justice system fails to ensure aboriginal traditional rights and dignity (Kent Roach, 2000: 273). It is arguing that traditional criminal justice system comes from western approach; therefore, this system is a mismatch with aboriginal traditional culture and value (Rupert Ross, 1995). There is a significant difference between the aboriginal justice system and predominant Canadian traditional criminal justice system. The Aboriginal justice system does not believe conventional litigation or as known as a winlose contest rather support the resolution by understanding (Rupert Ross, 1995: 433). Therefore, the

${ }^{4}$ Department of Justice. http://www.justice.gc.ca/eng/cj-jp/rj-jr/index.html. Date of accessed: 2nd December 2017. 
government of Canada has adopted aboriginal alternative justice program models known as sentencing circles, elder panels, healing circles, and elder or community assisted (parole) hearings.

All the processes are practice fairly without bias. These alternative system has introduced because of the study shows that the Canadian criminal justice system cannot tackle aboriginal offenders effectively (Julian V. Roberts, 1995; Jennifer Tufts, 2000). Because, aboriginal have a special background such as their customs, heritage, and believe different from traditional contemporary Canadian. On the other hand, modern Canadian people's origin was Europe, and they have introduced their European law and culture in Canada. There is a big difference between European laws and Canadian origin's (aboriginal) traditional customs. The aboriginal background contradicts Canadian traditional criminal procedural system. As a result, aboriginals overrepresented in the Canadian prison.

In (R. v. Gladue, 1999 at 52) justice of the Supreme Court of Canada opine:

"Canada is a world leader in many fields, particularly in the areas of progressive social policy and human rights. Unfortunately, our country is also distinguished as being a world leader in putting people in prison".

As the Canadian traditional criminal justice process is different from the aboriginal background, therefore, the aboriginal peoples are unable to comply with the Canadian traditional criminal law. Because the western legal system suppressed the aboriginal traditional justice dispute resolution process, while the restorative justice system is trying to reexamine as well as reactivate previous tradition system. In this regard, the (Law Commission of Canada, 2003 at 69) points out that:

"The very nature of restorative justice processes and their emphasis on informality rejects the one-size-fits-all approach of the traditional adjudicative model".

As aboriginal is the origin in Canadian, therefore, they have right to protect their unique background. Due to meet their particular background government should introduce alternative process following by aboriginal special knowledge, and from that point of view, the restorative justice theory may deem fit and appropriate in the criminal justice system in Canada.

In favour of the restorative justice process, study shows that victims are highly satisfied with the outcome of restorative justice process in Canada (Jeff Latimer and Steve Kleinknecht, 2000). They opine that the process is impartial. They also mentioned that they are much less satisfied with the traditional court process, and their satisfaction level appears to be related to the fulfilment of restitution agreement. Similarly, offenders also express high satisfaction with the restorative justice system and think that the system is unbiased (Jeff Latimer and Steve Kleinknecht, 2000: 16). Also, the offender mentioned that they are less satisfied with the traditional court system. The study also shows that most of the restorative justice process participants have a high level of success in negotiating restitution agreements than that of court order restitution.

\section{Restorative Justice Theory and Gladue Court in Canada}

It is an open-ended debate among the restorative justice theorists that, some theorists believe that the restorative approach may permissible only when crime and wrongdoing to be an offence against an individual or community, rather than a state (Price Marty, 2000: 11). They argue that a community may not be a state-party for resolving a grievous criminal offence rather state will prosecute in the serious criminal justice process. Thus, in case of grievous criminal offence restorative justice may not be implemented.

Now the question is who should deal with rule breaking as a legal authority? It is a familiar concept in a democratic country that the state will deal with the rule-breaking along with court and law enforcing agency.

However, restorative justice system suggests that respective communities can play a significant role in dealing with rule breaking (Robinson et al., 1995). Because a specialized individual's community member may adequately realize community's internal values. From that point of view, the $R v$. Gladue court's initiative was one of the most effective and appropriate steps for following restorative justice system.

Because, the objective of the law, legal body, and legal authorities is to regulate the behaviour of people within their own community (Lawrence W. Sherman and Heather Strang, 2007b: 350). So the question is, does Canadian traditional criminal court adequately legalize aboriginal behaviour? Definitely not. Therefore, the authority has to concern with understanding the ethical outline through which the public views their actions. In particular judicial body have to be sensitive to Aboriginal people's judgments about what makes legal procedure fair. 
People perception in restorative justice is that this approach is suitable for comparatively minor offence or for first time offender. However, the experience has shown that the restorative approach has greater result in more serious offences. Also, if the ideologies of restorative justice will take seriously, the best outcome will come from the restorative approach (Lawrence W. Sherman and Heather Strang, 2007b: 350).

The R. v. Gladue fact straight a crime against the state and state is a prosecutor. From that point of view, what was the legitimacy to follow restorative justice process in Gladue court? The Gladue court has the legitimacy to follow restorative justice approach not only because the fact is an aboriginal issue but also as a judicial obligation where Canadian Criminal Code guided Gladue court to follow the alternative process. Therefore, the sentencing court follows it judicial obligation according to section: 718.2 (e) of the Canadian Criminal Code, and quoted (R. v. Gladue, 1999) that:

"all available sanctions, other than imprisonment, that are reasonable in the circumstances and consistent with the harm done to victims or to the community should be considered for all offenders, with particular attention to the circumstances of Aboriginal offenders".

Even though, it can be criticized that the Supreme Court has not given a further guideline that how this section will be used by the trial court, how this section will be interpreted for using restorative justice theory. Basically, integration of specialized aboriginal knowledge or adverse circumstances of aboriginal community comes from aboriginal history, origin, culture, and inherent habit of their society (Paula Maurutto and Kelly HannahMoffat, 2016). However, the sentencing court did not found that types of issues involving in Gladue fact. Therefore, the Gladue court has taken into consideration aboriginal people overrepresentation in prisons, without considering aboriginal history, origin, culture, and inherent habit of their society. Though, the Gladue court has not found any special consideration given by the sentencing judge to accused's aboriginal background govern by section: 718.2 (e) of Canadian Criminal Code, 1985. However, the court argues (R. v. Gladue, 1999) that:

"It is remedial in nature and is designed to ameliorate the serious problem of overrepresentation of aboriginal people in prisons, and to encourage sentencing judges to have recourse to a restorative approach to sentencing".

In supporting this argument, statistical evidence shows that the aboriginal adults make up about 3 percent of the Canadian population, but they represent nearly 30 percent of admissions to provincial/territorial/federal custody (Reitano Julie, 2017). Another study shows about 39 percent of youth aboriginal were admitted to custody in 2015/2016, despite making up only 7 percent of Canada's youth population (Malakieh, Jamil, 2015/2016). The study also reveals that $2 / 3$ of crimes are committed by white under the influence of drugs or alcohol (Office of the Correctional Investigator, 2015). However, they are not proportionately representing in prison. According to this statistics, it can opine that it was an appropriate decision taken by the Gladue court to set up a new guideline (restorative justice theory) for sentencing aboriginal people in Canada. Because it is a special type of criminal court that acknowledge specialized aboriginal knowledge.

As far as serious criminal offence is a concern, it can argue that the theory of restorative justice does not prohibit to try serious criminal activities rather encourage to resolve by community representation, because this approach allows the offender to compensate victim directly, regardless the gravity and nature of the offence (Leo Zaibert, 2006). Moreover, victims can testify about the crime's impact upon their lives, receive answers to questions about the incident as well as holding accountable for his cirmes (Restorative Justice). Even though, a critic may think that the restorative justice approach is not fit for such nature of crime decided by the Gladue court. To answer the question Howard Jehr (2015) can be referred that the restorative justice system is not only fit for a particular purpose, or only for a social justice system rather it may fit for any type so offence regardless the nature and gravity of the crime.

\section{Success of Restorative Justice Process}

The crime in our society is well rooted in both private and public dimension. Existing legal system focuses on public dimension as a part of society's interest and obligation. However, it can be opined that in private sector crime restorative justice seeks to provide a better balance in how we experience justice. Also, in the traditional criminal justice system has some occasional gaps, as when a judge falls asleep during the trial. Such lapses do not abolish the whole justice system, rather try to make up the gapes to keep the judicial process in practice. Regarding visibility to anyone besides the offender, traditional criminal justice hardly has more people in the room than restorative justice process (Roche D, 2003). Therefore, restorative justice process will have the same effect for detection of violations of relevant rules as conventional criminal justice. 
Furthermore, the restorative justice advocates claim that this process can provide offenders, victims as well as communities creative and flexible sanctions that ensure a significant attempt to meet their long-term needs (Marshall, 1999). They argue restorative justice process do not get free the offender rather offenders remain responsible for following some guidelines given as an outcome of the restorative process (Law Commission of Canada, 2003). In (R. v. Proulx, 2000), the Supreme Court of Canada opined that:

"Restorative justice is accomplished, in part, through the rehabilitation of the offender, reparations to the victim and to the community and the promotion of a sense of responsibility in the offender and acknowledgement of the harm done to victims and to the community".

Therefore, restorative justice process does not conflict with the rule of law and it also not conflicts with the basic structure of common law rather in few cases restorative justice process may offer better results within the same basic principles. For example, in question answer, face to face interview has found that peoples are far from the practice of law, while the restorative justice approach reinforces the rule of law (Lawrence $\mathrm{W}$ Sherman and Heather Strang, 2007b). therefore, in recent, restorative justice process in England and Wales have been developed in four setting such as neighborhood policing, schools, adult and youth justice, and one of the restorative justice approaches in Hampshire (UK) was succeed that was previously successfully used in Canada (Lawrence W Sherman and Heather Strang, 2007b: 52).

Regarding obey a restorative justice agreement, result finds that 98 percent of offenders fulfil the outcome of an agreement reached in a consensual group discussion (Shapland et al., 2006). The same success has reported in four Canberra RISE tests (Strang, H., 2002). In a question of reducing harm to victims, the study found meaningfully more of those who have faced restorative justice conference were satisfied, compared with those whose cases were dealt with in court (70\% vs 42\%) (Lawrence W. Sherman and Heather Strang, 2007b). In terms of satisfaction, between restorative justice assigned victims and court-assigned victims, results shows restorative justice assigned 60 percent and court assigned victims 46 percent level satisfied, again victim's overall satisfaction with the restorative justice approach was 69 percent, where court-based approach justice level of satisfaction was 48 percent, and in terms of apologies, more conference-assigned victims than courtassigned victims said they felt the apologies (77\% vs 41\%) (Lawrence W. Sherman and Heather Strang, 2007b: 63). Moreover, 96 percent victims, who attended a conference felt that the restorative justice process was fair, 93 percent offender was held accountable, 94 percent agreed that their opinion had sufficiently considered, and 96 percent offender had apologized (McCold, P and Wachtel, B. 1998).

The North America numerous studies prolonging more than a decade finds high levels of victims satisfaction arising from the restorative justice opportunity (Nugent et al., 2003). In the restorative process, victims opine that they are more satisfied than their counterparts whose cases have dealt with in the formal justice system (McGarrell et al., 2000). In sum, it can be said that the restorative criminal justice process is more suitable than that of Canadian traditional criminal justice process.

\section{Conclusion with Recommendation}

From both theoretical and practical point of view, this study decides that the restorative justice theory is a suitable theory for aboriginal criminal justice process in Canada. This theory is allowed even for serious offence and violence, even though, a small number of restorative justice programs are dealing with serious offence and violent crimes (Ottawa, 2001). As a success of restorative justice theory, it may summarize that victims who receive restorative justice did better and satisfied than that of victims who do not receive restorative justice as a whole of outcomes. Offenders who receive restorative justice commit fewer repeat crimes than that of offenders who do not receive restorative justice. Restorative justice decreases repeat offending more frequently with violent crimes than with less serious crimes and this theory does not contradict with the rule of law rather it is part of the basic model of the criminal justice process.

Therefore, this paper recommends 'courtroom' restorative justice process, more precisely an "elder penal circle" who will take seats in a traditional courtroom for advising judge about accused and victim's cultural and specialized background. It may play an important role as well as will ensure the fundamental justice for aboriginal people in Canada. This paper also suggests 'sentencing circle' restorative justice process where community members will take seats in the community along with victim and offender. This group will recommend to court as well as other criminal court officials about their decision, and after that court will take a final decision. This system first took place in Canada in 1992 (R. v. Moses, 1992). Both these systems will ensure restorative justice as well as a quasi-judicial process where to maintain both traditional criminal court process along with specialized aboriginal knowledge. However, this paper does not suggest to follow 'healing 
circle' restorative justice system for serious criminal offence, since this process does not allow court involvement in any stage of the settlement. This process keeps the offender away from court involvement. In 'healing circle,' participants meet together in a circle and discuss the crime and prepare a layout plan of action. If they reach an agreement, the offender will not send to court. Therefore, this process has the possibility of bias. As far as parole provision of aboriginal people is also a concern, this paper suggests for an alternative process of conventional parole board hearing, this study suggests elder community member participate in conventional parole board hearing, and parole board will consider elder as an expert opinion.

Moreover, community-based police can cooperate with citizens to resolve community problems. Thus this study suggests developing community-based police (Weitekamp et al., 1996: 16). For instance, study (Lawrence W Sherman and Heather Strang, 2007b: 351) reveals that:

"The New York City Police Department feels considerable pride in their adoption of innovative policing techniques, such as COMPSTAT, which have enabled them to fight crime more effectively. However, views about the NYPD continue to be widely negative, especially among members of the minority community".

Therefore, the study also proposes restorative problem-solving system involving four groups such as police, community, offender and victim, and it will be a more efficient process for curbing future crime and will not contradict with the norms, aims and objectives of criminal justice outcome in Canada rather it will be costeffective, reduce case backlog as well as greater community confidence in justice.

\section{References}

1. Braithwaite, John (2002). Restorative Justice and Responsive Regulation. Oxford: Oxford University Press.

2. Braithwaite, John (1998). Restorative Justice in Tonry, M (ed) Handbook of Crime \& Punishment. Oxford: Oxford University Press.

3. Centre for Justice and Reconciliation. Available at http://restorativejustice.org/restorativejustice/\#sthash.VVlTh6Xp.dpbs. Date of accessed: $6^{\text {th }}$ December 2017.

4. Daubney, David (2002). Nine words: A response to empty promises. Parliament, the Supreme Court, and the sentencing of aboriginal offenders. Saskatchewan Law Review, 65, 35-52.

5. Haggard, Stephan, MacIntyre, Andrew and Tiede, Lydia (2008). The Rule of Law and Economic Development. Annual Review of Political Science, Vol. 11. Available at https://doi.org/10.1146/annurev.polisci.10.081205.100244.

6. Latimer, Jeff and Kleinknecht, Steve (2000). The Effects of Restorative Justice Programming: A Review of the Empirical. Available at http://www.justice.gc.ca/eng/rp-pr/csj-sjc/jsp-sjp/rr00 16/p2.html\#sec2 1 . Date of accessed: $6^{\text {th }}$ December 2017.

7. Law Commission of Canada (2003), pp. 61-62.

8. Malakieh, Jamil, (2015/2016). Youth correctional statistics in Canada. Statistics Canada.

9. Marshall, Tony F. (1999). Restorative Justice: An Overview Home Office. Research Development and Statistics Directorate. London, UK. Available at http://www.homeoffice.gov.uk/rds/pdfs/occ-resjus.pdf.

10.Maurutto, Paula and Hannah-Moffat, Kelly (2016). Aboriginal Knowledge in Specialized Courts: Emerging Practices in Gladue Courts. Canadian Journal of Law and Society / Revue Canadienne Droit et Société, 31(3): 451-471. doi:10.1017/cls.2016.35. Date of accessed: 30 ${ }^{\text {th }}$ November 2017.

11.McCold, P and Wachtel, B. (1998). Restorative Policing Experiment: The Bethlehem Pennsylvania Police Family Group Conferencing Project. Pipersville, Pennsylvania: Pipers Press.

12.McGarrell, E, Olivares, K, Crawford, K and Kroovand, N. (2000). Returning Justice to the Community: The Indianapolis Restorative Justice Experiment. Indianapolis, Hudson Institute.

13.McMurray, Foster (1955). Preface to an Autonomous Discipline of Education. Educational Theory. 5(3), 129-140. doi:10.1111/j.1741-5446.1955.tb01131.x. Date of accessed: 20 November 2017.

14.National Parole Board (January 2002). Government of Canada. Facts: Hearings for Aboriginal Offenders.

15.Native Counselling Services of Alberta (Ottawa, 2001). A Cost-Benefit Analysis of Hollow Water's Community Holistic Circle Healing Process, Aboriginal Corrections Policy Unit, Solicitor General Canada.

16.Nugent, W, Williams, M and Umbreit, M, (2003). Participation in Victim-Offender Mediation and the Prevalence and Severity of Subsequent Delinquent Behavior: A Meta-Analysis. Utah Law Review. 2003 (1), 137-166.

17.Office of the Correctional Investigator (2015). Annual Report of the Office of the Correctional Investigator 2014-2015.

18.Price, Marty (2000). Personalizing Crime. Dispute Resolution Magazine. 7(1), 8-11.

19.Reitano, Julie (2017). Adult correctional statistics in Canada, 2015/2016. Statistics Canada. 
20.Restorative Justice. Available at https://en.wikipedia.org/wiki/Restorative_justice\#cite_ref-32. Date of accessed: $30^{\text {th }}$ November 2017.

21.Roach, Kent (2000). Changing Punishment at the Turn of the Century: Restorative Justice on the Rise. Canadian Journal of Criminology, 42(3), 273.

22.Roberts, Julian V. (1995). Sentencing, Public Opinion and the News Media. 26(1), Revue générale de droit.

23.Robinson, Paul H., and John M. Darley (1995). Justice, Liability, and Blame: Community Views and the Criminal Law, (Boulder, Colo.: Westview)

24.Roche D. (2003). Accountability in Restorative Justice" (Oxford: Oxford University Press). p. 194-198.

25.Ross, Rupert (1995). Exploring the Aboriginal Paradigm. Saskatchewan Law Review. 59(2).

26.Shapland, J, Atkinson, A, Atkinson, H, Chapman, B, Colledge, E, Dignan, J, Howes, M, Johnstone, J, Robinson, G and Sorsby (2006). Restorative Justice in Practice: The Second Report from the Evaluation of Three Schemes (Sheffield: Centre for Criminological Research, University of Sheffield).

27.Sherman, Lawrence W (1999). Consent of the Governed: Police, Democracy, and Diversity. Paper presented at a conference in honour of Professor Menachem Amir, Institute of Criminology, Hebrew University of Jerusalem, Jerusalem, January 7.

28.Sherman, Lawrence W. \& Strang, Heather (2007a). Restorative Justice: The Evidence. University of Pennsylvania.

29. Sherman, Lawrence W. and Strang, Heather (2007b). Restorative Justice" (Published by the Smith Institute, 2007). Available at http://www.iirp.edu/pdf/RJ full report.pdf. Date of access $9^{\text {th }}$ December 2017.

30.Strang, H. (2002). Repair or Revenge: Victims \& Restorative Justice" (Oxford: Oxford University Press).

31.Tufts, Jennifer (2000). Public Attitudes Towards the Criminal Justice System. Juristat, Canadian Centre for Justice Statistics, Statistics Canada. 20(12).

32.Tyler, Tom R. (2003). Procedural Justice, Legitimacy, and the Effective Rule of Law, 30 Source: Crime and Justice. The University of Chicago Press. pp. 283-357.

33.United Nations, Office of Drugs and Crimes (2006). Handbook on Restorative justice programmes. New York: United Nations publication.

34.Van Ness, Daniel W., Karen Heetderks Strong (2010). Restoring Justice - An Introduction to Restorative Justice, 4th ed. New Province, N.J.: Matthew Bender \& Co., Inc., pp. 21-22.

35.Weitekamp, Elmer G. M., Hans-Jurgen Kerner, and Ulrike Meier (1996). Problem-Solving Policing: Views of Citizens and Citizen's Expectations. Paper presented at the international conference on problem-solving policing as crime prevention. Stockholm, September. P. 16.

36.Wikipedia. Restorative Justice. Available at https://en.wikipedia.org/wiki/Restorative_justice. Date of accessed: 23rd November 2017.

37.Zaibert, Leo (2006). Punishment And Retribution. (Ashgate Publishing).

38.Zehr, Howard (2015). The Little Book of Restorative Justice: Revised and Updated (Justice and Peacebuilding). New York: Good Books Publisher. Available at https://lop.parl.ca/Content/LOP/ResearchPublicationsArchive/bp1000/prb0339-e.asp\#brestorativetxt. Date of accessed: $20^{\text {th }}$ November 2017.

\section{Case Reference}

R. v. Borden, [1994] 3 S.C.R. 145

R. v. Gladue, [1999] 1 SCR 688, 1999 CanLII 679 (SCC)

R. v. Ipeelee, 2012 SCC 13, [2012] 1 S.C.R. 433

R. v. Kakekagamick (M.R.), (2006) 214 O.A.C. 127 (CA)

R. v. Moses, [1992] Y.J. No. 50.

R. v. Proulx [2000] 1 S.C.R. at 18. 